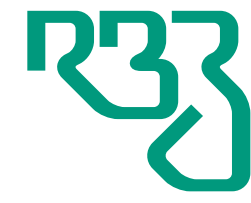

Revista Brasileira de Zootecnia

Brazilian Journal of Animal Science ISSN 1806-9290

www.rbz.org.br

\section{Effectiveness of a low-dose Norgestomet ear implant in short-term protocols to induce estrus in ewes during the non-breeding season in Brazil}

\author{
Dayrton Farias Lima Júnior ${ }^{1}$ iD , José Victor Pronievicz Barreto ${ }^{2 *}$ iD, \\ Fabiana de Andrade Melo Sterza ${ }^{3}$ (iD), Mirela Brochado Souza-Cáceres ${ }^{4}$ (iD), \\ Vanessa Pereira Pontes ${ }^{5}$, Marilice Zundt ${ }^{6}$ (iD), Caliê Castilho ${ }^{6}$ (iD), Luiz \\ Fernando Coelho da Cunha Filho ${ }^{2}$ iD \\ ${ }^{1}$ Universidade Pitágoras Unopar, Centro de Ciências Agrárias, Arapongas, PR, Brasil. \\ ${ }^{2}$ Universidade Pitágoras Unopar, Programa de Pós-Graduação em Saúde e Produção Animal, \\ Arapongas, PR, Brasil. \\ ${ }^{3}$ Universidade Estadual de Mato Grosso do Sul, Programa de Pós-Graduação em Zootecnia, \\ Aquidauana, MS, Brasil. \\ ${ }^{4}$ Universidade Estadual de Londrina, Programa de Pós-Graduação em Ciência Animal, \\ Londrina, PR, Brasil. \\ ${ }^{5}$ Universidade Estadual do Oeste do Paraná, Programa de Pós-Graduação em Zootecnia, \\ Marechal Cândido Rondon, PR, Brasil. \\ ${ }^{6}$ Universidade do Oeste Paulista, Programa de Pós-Graduação em Ciência Animal, \\ Presidente Prudente, SP, Brasil.
}

\begin{abstract}
The objective of this study was to evaluate the reproductive performance of ewes subjected to a short-term protocol for estrus induction using $1 \mathrm{mg}$ of Norgestomet during the non-breeding season in Brazil. A total of 84 ewes were randomly divided into two equal groups ( $n=42$ per group). Controlled Internal Drug Release (CIDR) containing $330 \mathrm{mg}$ progesterone was inserted into the vagina in the first 42 ewes, and for the other 42 ewes in the second group, $1 \mathrm{mg}$ of Norgestomet was placed subcutaneously in the convex surface of the ear. Implants and devices were removed in both groups on day 6. Following the removal of implants and devices, $10 \mathrm{mg}$ of PGF2 $\alpha$ and $300 \mathrm{IU}$ of eCG were injected in all the ewes. After $48 \mathrm{~h}$ of application, three fertile rams were added to the herd. Ewes and rams were kept together for four days. Rams were removed on day 12 , and after 42 days, pregnancy was diagnosed by ultrasound scanning. Short-term protocols using either an intravaginal device or ear implant were similarly effective to estrus induction ( 95.23 vs. $92.85 \%$ ), and all ewes from both groups had estrus manifestation within $72 \mathrm{~h}$ after implant removal $(72 \pm 9 \mathrm{~h})$. In addition, no significant difference in pregnancy rate was observed between ewes treated with the intravaginal device and ear implant protocols (52.38 vs. $57.14 \%$ ). These results suggest that $1 \mathrm{mg}$ of Norgestomet is a good alternative for short-term protocols for estrus induction/ synchronization during the non-breeding season in ewes. It is possible to replace the progesterone-releasing intravaginal device by the ear implant and obtain the same reproductive effectiveness in ewes.
\end{abstract}

Keywords: animal breeding, ovine, progesterone, reproductive traits, sheep, synchronization of estrus

\title{
Introduction
}

The reproductive seasonality of ewes is an important limiting factor that interferes in the obtention of lambs. The control of reproductive function in ewes has become an important aspect of livestock 
production, especially where reproduction is affected by photoperiod (Takada et al., 2012). Studies have thus been performed to describe the effects of seasonality on changes in the reproductive tract of ewes and to evaluate the hormonal induction to improve fertility (Garoussi et al., 2012).

Estrus synchronization using synthetic analogues of progesterone administered through intravaginal devices is the main method used for hormonal induction and/or estrus synchronization in small ruminants (Traldi et al., 2007; Takada et al., 2012). However, the use of progesterone-releasing intravaginal devices for long periods is laborious and has been associated with the excess accumulation of vaginal mucus (Suárez et al., 2006). Furthermore, there is a deleterious effect of excessive progesterone on the transport of spermatozoa in the female genital tract (Quinlivan and Robinson, 1969). Thus, the use of short-term protocols and different hormonal protocol approaches must be considered.

The use of Norgestomet implants inserted subcutaneously in the back of the ear has been reported to improve fertility in ewes (Castilho et al., 2007; Awel et al., 2009; Garoussi et al., 2012; Santos and Barcelos, 2012; Dogan et al., 2018). However, the use of commercial doses of Norgestomet in ewes is still in the incipient stages compared with the use of other devices, and further studies are necessary to evaluate its effects on animal reproduction. Half and entire Norgestomet ear implants were equally efficient to synchronize and induce estrus in ewes during natural anestrous (Dogan et al., 2018). Nevertheless, there is no study about estrus induction using less than a half ear implant.

Searching for alternative methods that are both efficient, effective, and economically viable is crucial for optimizing the results of reproductive management in ewes. Therefore, in this study we evaluated whether a third of the commercial Norgestomet implant may be used to increase reproductive success in ewes and, consequently, reduce animal production costs. The present study aimed to evaluate the reproductive performance of ewes treated with short-term protocols for estrus induction and/or synchronization using $1 \mathrm{mg}$ of Norgestomet during the non-breeding season in a tropical country (Brazil).

\section{Material and Methods}

All procedures were approved by the local Ethical Committee for the care and use of experimental animals (CEA/UNOPAR 007/11). The experiment was conducted on a farm located at $24^{\circ} 41^{\prime} 00^{\prime \prime} \mathrm{S}$ latitude, $50^{\circ} 10^{\prime} 00^{\prime \prime}$ W longitude, and an altitude of 1,043 m, in Londrina, PR, Brazil. The climate of the study site is classified as Cfa according to the Köppen-Geiger system, and is characterized as a humid subtropical zone with rainforest throughout the year and no dry season. The observed annual maximum and minimum temperatures were 28.5 and $16.6^{\circ} \mathrm{C}$, respectively, and the total annual precipitation averaged $156.1 \mathrm{~mm}$.

All ewes were maintained on pastures containing Bermuda grass (Cynodon dactylon) and Tifton 85 (Cynodon dactylon cv. Tifton 85) during the day and were confined to enclosed barns during the nighttime. In practice, routine management procedures were carried out, including the treatment of animals with anthelmintics for external and internal parasites and vaccinations being carried out before the breeding season. The management of the ewes did not change throughout the entire study period. Animals were provided with water and mineral salt ad libitum.

The experiment was conducted between November and February (spring), which is considered a non-breeding season for ewes in Brazil (Pinna et al., 2012). This study used 84 Texel adult ewes, which were 12 to 18 months of age, with an average weight $( \pm S D)$ of $58.44 \pm 9.1 \mathrm{~kg}$ and a mean body condition score of 2.8 \pm 0.3 , on a scale from 0 (lowest) to 5 (highest) according to Russel (1991).

Previously to the hormonal protocol, the animals were examined by ultrasound (Honda HS101v ${ }^{\circledR}$, São Paulo, Brazil) in B-mode, equipped with a linear $7.5 \mathrm{MHz}$ transducer, aiming to confirm that the ewes were not pregnant and without ovarian activity, also confirming the natural anestrous.

Three rams were used, with an average age of three years. Andrological examinations of the rams were performed prior to their introduction into the flock. All rams were approved after the examinations confirmed their breeding soundness, as recommended by the CBRA (2013). The parameters of ram semen used in this work are shown in Table 1.

R. Bras. Zootec., 48:e20190062, 2019 
Table 1 - Seminal characteristics and scrotal circumference of three Texel rams

\begin{tabular}{lc}
\hline Seminal characteristic & Average \pm SD \\
\hline Sperm concentration $\left(\times 10^{9} \mathrm{sptz} / \mathrm{mL}\right)$ & $2.20 \pm 0.20$ \\
Volume $(\mathrm{mL})$ & $0.70 \pm 0.10$ \\
Gross motility (0-5) & $5.00 \pm 0.00$ \\
Progressive motility (\%) & $90.00 \pm 0.00$ \\
Vigor (0-5) & $5.00 \pm 0.00$ \\
Major defects (\%) & $5.30 \pm 2.80$ \\
Minor defects (\%) & $7.60 \pm 1.10$ \\
Total defects (\%) & $13.00 \pm 1.70$ \\
Scrotal circumference $(\mathrm{cm})$ & $34.50 \pm 1.80$ \\
\hline
\end{tabular}

SD - standard deviation.

Ewes were randomly allocated into two groups: 42 ewes received a treatment protocol that used a controlled intravaginal drug-releasing device containing $330 \mathrm{mg}$ of natural progesterone $\left(\right.$ CIDR $^{\circledR}$; Zoetis ${ }^{\circledR}$, São Paulo, Brazil); and the other 42 ewes were subjected to a protocol using a progestogen-releasing ear implant, from which they received $1 \mathrm{mg}$ of Norgestomet (Crestar ${ }^{\circledR}$; MSD Animal Health ${ }^{\circledR}$, São Paulo, Brazil). The commercially available $3 \mathrm{mg}$ dose of Norgestomet was divided into three equal parts, and each part (of $1 \mathrm{mg}$ ) was implanted subcutaneously on one ear of the ewes. In addition, we evaluated the price paid for the implants obtained in Brazilian currency (Reais; $R \$$ ) at the beginning of the study, and transformed it into the currency of the United States (US Dollars; US\$) based on exchange rates up to March 2019 (Bacen, 2019).

The short-term protocols used prior to breeding in this study were performed over a period of eight days. On day 0 (day 0), ewes received either the progesterone (intravaginal) or progestogen-releasing (ear) device. Six days later (on day 6), the device was removed from all the ewes, and then injections of $10 \mathrm{mg}$ of dinoprost (PGF2 $\alpha$; Lutalyse ${ }^{\circledR}$; Zoetis, São Paulo, Brazil) and 300 IU of equine chorionic gonadotropin (eCG; Novormon ${ }^{\circledR}$, Syntex, Buenos Aires, Argentina) were administered intramuscularly. At day 8, the three rams were introduced among the ewes and remained for four days. All rams were marked with ink of different colors on the pectoral region. During this period, the occurrence of estrus was checked in the early morning and late afternoon, according to the ink marks, once that when the rams copulated with the ewes, the ink was deposited on the lumbar region of each ewe, indicating estrus.

Pregnancy diagnosis was performed 42 days after the removal of the rams. A single real-time ultrasound exam was performed on each ewe using a portable ultrasound unit (Honda HS101v ${ }^{\circledR}$, São Paulo, Brazil) in B-mode, equipped with a linear $7.5 \mathrm{MHz}$ transducer. The estrus synchronization protocol and ultrasound scheme performed on the ewes are illustrated in Figure 1.

The percent occurrences of estrus and pregnancy in both treatment groups were compared in our statistical analyses. All data were analyzed using the statistical software R (R Core Team, 2014) with a non-parametric analysis of variance (Wilcoxon rank-sum test), because the residuals were not normally distributed. The significance level considered was $5 \%$ probability.

Analyses of variance were performed considering the model:

$$
y_{i k}=\mu+t_{i}+e_{i k^{\prime}}
$$

in which $y_{i k}$ are the observations, $\mu$ is the general mean, $t_{i}$ is the treatment effect, and $e_{i k}$ is the random error. 


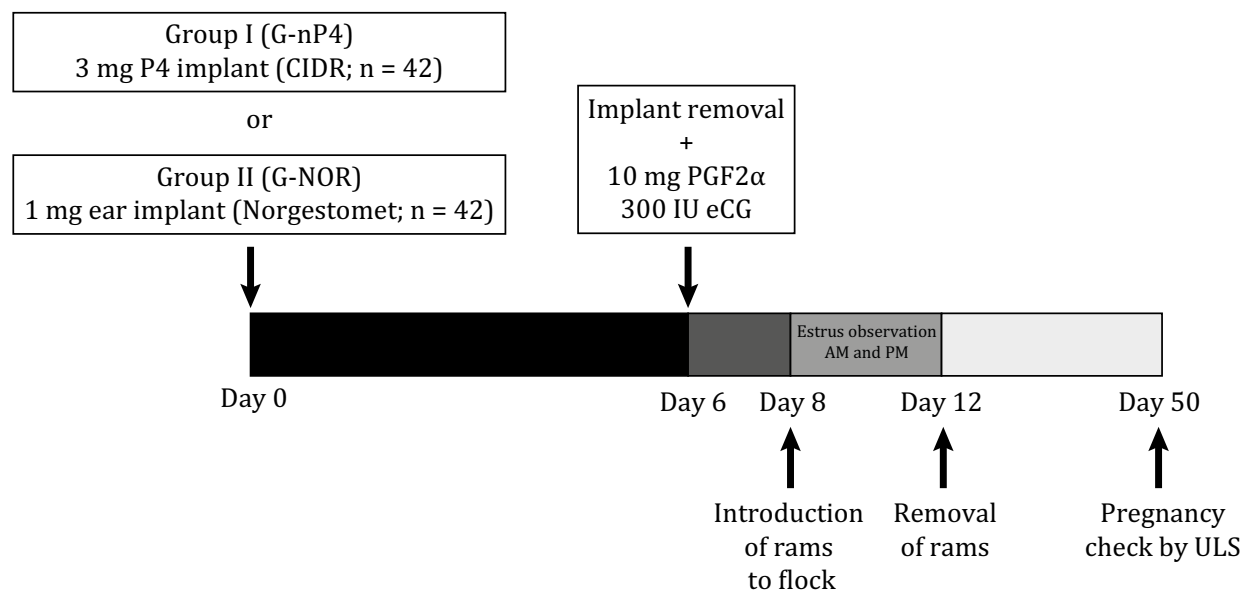

ULS - ultrasound.

Figure 1 - Schematic representation of the different synchronization protocols using an intravaginal progesterone device (G-nP4) or ear implant (G-NOR) in Texel ewes.

\section{Results}

Throughout the experimental period, all animals maintained the same body condition score. Ewes from both groups had estrus manifestation within $72 \mathrm{~h}$ after the implant removal $(72 \pm 9 \mathrm{~h})$. We observed that our short-term protocol with a progestogen-releasing ear implant was just as effective at inducing estrus as the protocol with the intravaginal device containing natural progesterone $(\mathrm{P}=0.65)$ (Figure 2). Pregnancy rates in ewes induced with the progestogen-releasing ear implant were similar (57.14 or $24 / 42$ ewes) to those in ewes induced with the progesterone-releasing intravaginal device (52.38 or 22/42 ewes), and no statistically significant difference was observed between these two groups $(\mathrm{P}=0.55)$ (Figure 2).

The mean costs of each protocol used in this study obtained from eight veterinary pharmacies were equivalent: US $\$ 7.73$ for the intravaginal device and US $\$ 7.93$ for the ear implant.

\section{Discussion}

The present study demonstrated that a one-third dose of the commercially available progestogen released from an ear implant had promising potential to be used to induce estrus cycle and increase pregnancy rates in ewes. Our results corroborate the findings of Santos and Barcelos (2012), who observed the effectiveness of a low-dose Norgestomet ear implant to induce estrus in ewes during the breeding season. In goats, Cruz et al. (2010) used 1/3 of a Norgestomet implant after its second reuse, and observed that $85.7 \%$ of animals manifested estrus, with a $100 \%$ incidence of pregnancy. Half

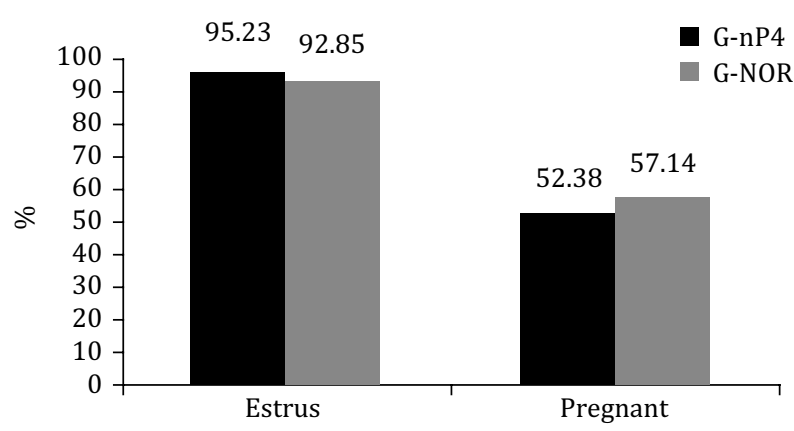

Figure 2 - Estrus response (\%) and pregnancy rate (\%) using an intravaginal progesterone device (G-nP4) or ear implant (G-NOR). 
and entire Norgestomet ear implants were equally efficient in synchronizing and inducting estrus in ewes during natural anestrus (Dogan et al., 2018). In ewes, Norgestomet ear implants were successfully reused to synchronize estrus in Texel (Bragança and Rocha, 2018).

Pendleton et al. (1992) compared the ability of a fluorogestone acetate (FGA) sponge to induce estrus and ovulation in anestrous dairy goats to that of implants containing Norgestomet and concluded that both were equally effective as part of the induction protocol. In small ruminants, the use of such progestogens, such as melengestrol acetate and fluorogestone for these purposes is well-established (Powell et al., 1996; Riesenberg et al., 2001; Rojo-Martínez and Salas-Razo, 2015; Rojo-Martínez et al., 2017). According to Cline at al. (2001), $3 \mathrm{mg}$ of Norgestomet was effective at inducing estrus in ewes during the breeding season, with average intervals from 36 to $74 \mathrm{~h}$ between the removal of the device and subsequent ovulation. In addition, pregnancy rates varied between 60 and $72 \%$ in ewes synchronized with protocols based on Norgestomet during the non-breeding season in previous studies (Awel et al., 2009; Garoussi et al., 2012; Uslu et al., 2012).

In ewes, progestogen treatments of long duration have been shown to negatively affect the fertility of animals, mainly due to the deleterious effect of this hormone on the transport of spermatozoa in the female genital tract (Quinlivan and Robinson, 1969). Vilariño et al. (2013) evaluated three uses of the Eazi-breed CIDR ${ }^{\circledR}$ for programs of estrus synchronization and/or induction; however, their results showed that the $1 / 3$ implant tended to be less efficient in generating pregnancies compared with newer devices. Therefore, the effects of subluteal progesterone concentrations on ovarian follicular dynamics should be evaluated. Despite the fact that all studies cited herein were carried out with different protocols, they all demonstrated satisfactory results, since more than $50 \%$ of the females became pregnant during the first week of the induced reproductive nonbreeding season.

Progestin-impregnated vaginal pessaries may be used for the synchronization of estrus and ovulation and can be used in association with different hormones to obtain increased accuracy in the timing of induced ovulation (Abecia et al., 2012). Fleisch et al. (2012) used a six-day treatment with Chronogest ${ }^{\circledR} \mathrm{CR}$ and Eazi-breed CIDR ${ }^{\circledR}$ with prostaglandin and eCG at the implant removal and observed a high rate of estrus induction with both treatments ( 98.8 and $89.4 \%$, respectively) and similar fertility in cyclic ewes. It is also possible that estrus can be induced in anestrous ewes by a six- or 12-day treatment with a progestagen-impregnated intravaginal sponge (Amer et al., 2009).

In this study, estrus in ewes was successfully synchronized when ear implant containing low-dose Norgestomet treatment protocol was used during the non-breeding season.

Determining the cost of low-dose ear implant compared with the natural progesterone-releasing intravaginal device is crucial for determining the financial efficiency of different techniques and improving production efficiency. In this study, the protocols demonstrated a difference of only US $\$ 0.07$ between them. Indeed, the costs of the hormonal protocols used in the intravaginal device and ear implant were similar. Two formulations of Eazi-breed CIDR ${ }^{\circledR}$ were considered (per the manufacturer's recommendations) in this study, while the Crestar ${ }^{\circledR}$ doses used were divided into three equal parts with no reuses. We observed no significant differences between the percent occurrence of estrus and pregnancy between the groups evaluated, suggesting that both protocols have favorable costbenefit ratios. The results of this study emphasize the fact that both protocols were efficient for estrus induction, which should help to improve the results of reproductive management programs in the future.

\section{Conclusions}

The use of $1 \mathrm{mg}$ of Norgestomet in a short-term protocol during the non-breeding season demonstrated to be effective for estrus induction. 


\section{Conflict of Interest}

The authors declare no conflict of interest.

\section{Author Contributions}

Conceptualization: D.F. Lima Júnior and F.A. Melo Sterza. Data curation: M. Zundt and C. Castilho. Formal analysis: M.B. Souza-Cáceres. Investigation: L.F.C. Cunha Filho. Methodology: J.V.P. Barreto. Project administration: D.F. Lima Júnior, V.P. Pontes and L.F.C. Cunha Filho. Resources: L.F.C. Cunha Filho. Supervision: M. Zundt and L.F.C. Cunha Filho. Validation: C. Castilho and L.F.C. Cunha Filho. Writing-original draft: J.V.P. Barreto. Writing-review \& editing: J.V.P. Barreto.

\section{References}

Abecia, J. A.; Forcada, F. and Gonzáles-Bulnes, A. 2012. Hormonal control of reproduction in small ruminants. Animal Reproduction Science 130:173-179. https://doi.org/10.1016/j.anireprosci.2012.01.011

Amer, H. A. and Hazzaa, A. M. 2009. The effect of different progesterone protocols on the reproductive efficiency of ewes during the non-breeding season. Veterinarski Arhiv 79:19-30.

Awel, H.; Eshetu, L.; Tadasse, G.; Birhanu, A. and Khar, S. K. 2009. Estrus synchronization in sheep with synthetic progestagens. Tropical Animal Health and Production 41:1521-1524. https://doi.org/10.1007/s11250-009-9342-7

BACEN - Banco Central do Brasil. 2019. Available at: <http://www4.bcb.gov.br/pec/conversao/conversao.asp >. Accessed on: May 1, 2019.

Bragança, J. F. M. and Rocha, R. X. 2018. A reutilização de um implante de Norgestomet na manifestação de estro ovino. PUBVET 12:1-5. https://doi.org/10.22256/pubvet.v12n7a130.1-5

Castilho, C.; Mori, M. M.; Alessi, C. P. and Giuffrida, R. 2007. Indução do estro em ovelhas da raça Texell durante o anestro estacional utilizando meio implante de progestágeno novo ou reutilizado. Veterinária Notícias 13:39-45.

Cline, M. A.; Ralston, J. N.; Seals, R. C. and Lewis, G. S. 2001. Intervals from Norgestomet withdrawal and injection of equine chorionic gonadotropin or P.G. 600 to estrus and ovulation in ewes. Journal of Animal Science 79:589-594. https://doi.org/10.2527/2001.793589x

CBRA - Colégio Brasileiro de Reprodução Animal. 2013. Manual para exame andrológico e avaliação de sêmen animal. 3.ed. Belo Horizonte.

Cruz, M. H. C.; Cruz, J. F.; Moura, L. C. O.; Teixeira-Neto, M. R.; Ferraz, R. C. N.; Becker-Silva, S. C. and Snoeck, P. P. N. 2010. Eficácia de implantes de Norgestomet reutilizados no controle do ciclo estral de cabras leiteiras. Revista Brasileira de Medicina Veterinária 32:219-224.

Dogan, I.; Nur, Z. and Kilinc, B. 2018. Different estrus induction protocols and fixed time artificial insemination during the anoestrous period in non-lactating Kivircik ewes. Journal of the Hellenic Veterinary Medical Society 69:801-808. https://doi.org/10.12681/jhvms.16429

Fleisch, A.; Werne, S.; Heckendorn, F.; Hartnack, S.; Piechotta, M.; Bollwein, H.; Thun, R. and Janett, F. 2012. Comparison of 6-day progestagen treatment with Chronogest ${ }^{\circledR} \mathrm{CR}$ and Eazi-breed ${ }^{\mathrm{TM}} \mathrm{CIDR}^{\circledR} \mathrm{G}$ intravaginal inserts for estrus synchronization in cyclic ewes. Small Ruminant Research 107:141-146. https://doi.org/10.1016/j.smallrumres.2012.05.014

Garoussi, M. T.; Farzaneh, N.; Gallehdar, E. and Mohri, M. 2012. Reproductive performance in out-of-breeding season of fatty ewes using implant Norgestomet with or without PMSG. Tropical Animal Health and Production 44:965-968. https://doi.org/10.1007/s11250-011-9993-z

Pinna, A. E.; Brandão, F. Z.; Cavalcanti, A. S.; Borges, A. M.; Souza, J. M. G. and Fonseca, J. F. 2012. Reproductive parameters of Santa Inês ewes submitted to short-term treatment with re-used progesterone devices. Arquivo Brasileiro de Medicina Veterinária e Zootecnia 64:333-340. https://doi.org/10.1590/S0102-09352012000200012

Pendleton, R. J.; Youngs, C. R.; Rorie, R. W.; Pool, S. H.; Memon, M. A. and Godke, R. A. 1992. Comparison of fluorogestone acetate sponges with Norgestomet implants for induction of estrus and ovulation in anestrous dairy goats. Small Ruminant Research 8:269-273. https://doi.org/10.1016/0921-4488(92)90048-9

Powell, M. R.; Kaps, M.; Lamberson, W. R. and Keisler, D. H. 1996. Use of melengestrol acetate-based treatments to induce and synchronize estrus in seasonally anestrous ewes. Journal of Animal Science 74:2292-2302. https://doi.org/10.2527/1996.74102292x

Quinlivan, T. D. and Robinson, T. J. 1969. Numbers of spermatozoa in the genital tract after artificial insemination of progestagen treated ewes. Journal of Reproduction and Fertility 19:73-86. https://doi.org/10.1530/jrf.0.0190073 
R Core Team. 2014. R: A Language and Environment for Statistical Computing. R Foundation for Statistical Computing, Vienna, Austria.

Riesenberg, S.; Meinecke-Tillmann, S. and Meinecke, B. 2001. Ultrasonic survey of follicular development following superovulation with a single application of pFSH, eCG or hMG in goats. Small Ruminant Research 40:83-93. https://doi. org/10.1016/S0921-4488(00)00211-X

Rojo-Martínez, J. A. and Salas-Razo, G. 2015. The use of melengestrol acetate as a strategy to improve production efficiency of sheep in rural areas in Mexico. Journal of Agricultural Science and Technology A 5:210-213. https://doi. org/10.17265/2161-6256/2015.03.009

Rojo-Martínez, J. A.; Piña, R. G.; Caratachea, A. J.; Patiño, A. B.; Villavicencio, J. L. E. and Razo, G. S. 2017. Estrus, fertility and prolificacy in wool sheep treated with melengestrol acetate on the reproductive and non-reproductive period. Transylvanian Review 25:5689-5695.

Russel, A. 1991. Body condition scoring of sheep. In: Sheep and goat practice. Boden, E., ed. Bailliere Tindall, Philadelphia.

Santos, F. C. C. and Barcelos, R. A. D. 2012. Eficiência de protocolos de sincronização de estro em ovelhas. Revista Brasileira de Reprodução Animal 36:202-205.

Suárez, G.; Zunino, P.; Carol, H. and Ungerfeld, R. 2006. Changes in the aerobic vaginal bacterial mucous load and assessment of the susceptibility to antibiotics after treatment with intravaginal sponges in anestrous ewes. Small Ruminant Research 63:39-43. https://doi.org/10.1016/j.smallrumres.2005.01.011

Takada, L.; Bicudo, S. D.; Rodrigues, C. F. C.; Coelho, L. A.; Mendes, L. C. N. and Perri, S. H. V. 2012. Ovarian response of Suffolk ewes to estrous synchronization using short-term protocol. Revista Brasileira de Zootecnia 41:314-319. https://doi.org/10.1590/S1516-35982012000200012

Traldi, A. S.; Loureiro, M. F. P.; Capezzuto, A. and Mozorra, A. L. 2007. Métodos de controle da atividade reprodutiva em caprinos. Revista Brasileira de Reprodução Animal 31:254-260.

Uslu, B. A.; Tasal, I.; Gulyuz, F; Sendag, S.; Ucar, O.; Goericke-Pesch, S. and Wehrend, A. 2012. Effects of oestrus synchronisation using melatonin and Norgestomet implants followed by eCG injection upon reproductive traits of fat-tailed Morkaraman ewes during suckling, anoestrus season. Small Ruminant Research 108:102-106. https://doi. org/10.1016/j.smallrumres.2012.07.002

Vilariño, M.; Rubianes, E. and Menchaca, A. 2013. Ovarian responses and pregnancy rate with previously used intravaginal progesterone releasing devices for fixed-time artificial insemination sheep. Theriogenology 79:206-210. https://doi.org/10.1016/j.theriogenology.2012.10.007 